\title{
PHYSICAL CHARACTERISTICS OF THE ENTRANCE AREAS OF CROSS PASSAGE ALONGSIDE JL. AGRO, YOGYAKARTA
}

\author{
Yurista Hardika Dinata ${ }^{*}$, Djoko Wijono ${ }^{2}$ \\ ${ }^{1}$ Student at the Graduate Program in Architecture, Department of Architecture and Planning, Faculty of Engineering, Universitas \\ Gadjah Mada, Yogyakarta, Indonesia \\ ${ }^{2}$ Lecture at the Graduate Program in Architecture, Department of Architecture and Planning, Faculty of Engineering, Universitas \\ Gadjah Mada, Yogyakarta, Indonesia
}

\section{ABSTRACT}

This study aimed to determine the physical characteristics of the entrance areas of cross passage alongside Jl. Agro, Yogyakarta. The method used was descriptive exploratory, with superimposed analysis techniques. Meanwhile, the number of observed cases was determined by purposive sampling technique. The research results showed that commercial buildings with a short seatback constructed the wall space around the entrance areas of cross passage. The scale of the road space was formed by a combination of balanced and narrow space affected by the height of the building. Street floor space, signage, and vegetation showed different patterns at each entrance areas of cross passage. As part of street furniture, gate and sculpture turned into a strong identity in the cross-passage area. There were nine entrance areas of cross passage as a case of observation. The nine cases' physical appearance showed the distinctive form of the archipelago and local identity as three different elements bound them: urban village area as a local identity, Selokan Mataram Canal as a heritage of the agricultural system, and universities as a generator of activity.

\section{Keywords:}

characteristics, area, entrance of cross passage

\section{Introduction}

Kampung Kota (urban village) is an area that is formed authentically. It is a manifestation of the urban environment. Such areas are often found in urban areas in Indonesia. The striking physical characteristics of the urban village are the connecting paths, also known as cross passage. These cross passages do not only function as movement spaces, but also as a social space, even a room with residents (Pangarsa, 2010: 38). One of the manifestations of the shared space is as a medium for conducting outdoor activities, gathering with other neighbors, and becoming spaces for children's outdoor activities (Setiawan, 2008: 27). Due to villages have limited residential area, the road on cross passage is used as an additional space for outdoor activities. In this case, junction areas are the signs that connect the main road and cross passage.

One of the entrance areas of cross passage having the authentic characteristics of the urban area is the one located near the northern part of road corridor of J. Agro, Yogyakarta. The entrance areas of cross passage show the identity of the urban villages located along the road corridor. In addition to demonstrating the manifestation of typical urban housing, the entrance areas of cross passage have a unique identity: each entrance area of cross passage is on the edge of Selokan Mataram Canal. Jl. Agro itself is the detection path in the southern and northern part of Selokan Mataram Canal. According to history, Selokan Mataram Canal is the longest agricultural system damage in Indonesia. Moreover, another feature is that along the southern part of Jl. Agro is located a cluster of universities, namely Universitas Gadjah Mada and Universitas Negeri Yogyakarta. Those universities also act as a generator of activity on the road, mainly centering on the intersection of cross passage entrance.

According to the history, road space and area along $\mathrm{Jl}$. Agro has experienced 6 (six) transformations in terms of developing the region. In 1991, the residential construction at the edge of canal was rising; in 2003, it started to develop until the northern part, and as time went by, the rural area turned to be commercialized. Furthermore, in 2008, the number of buildings went up, and the village streets were unorganized (Hakim, 2010: I-10). Later on, there was revitalization on the road space floor in 2009 and 2012, as well as land acquisition and infrastructure improvement (Wismarani, 2017: 204). Finally, in 2019, there was a medium-scale road revitalization carried along with the improvement of drainage. On beheaded of Jl. Kaliurang 
until Gang Gayamsari 1 (Gayamsari 1 Cross passage), the road's width increased by $1 \mathrm{~m}$, and the pedestrian path increased by $0.5 \mathrm{~m}$ from initially $1.5 \mathrm{~m}$ to $2 \mathrm{~m}$. As time went on, the land conversion was rising, and the most striking of all was that on the center of activity, that is the entrance areas of cross passage. If it happened continuously, it would have an impact on the decline in the physical quality of the region and, further, it can eliminate the village's authentic characteristics, which will continue to transform new characters.

Starting from the understanding that urban village is an authentic form of the urban environment, an inventory of regional identity is needed in realizing the physical characteristics of the area at each cross passage along J. Agro, Yogyakarta. This physical change will probably continue since the entrance areas of cross passage, precisely the research site, are the edge and the core. The entrance areas of cross passage are a slice of 3 different elements of the region: urban village, Selokan Mataram Canal, and universities.

\section{Literature Review}

Rapoport (1977: 332) argues that human security in the community has made certain choices in forming a space. Since the choice is influenced by style, the establishment of a consistent space should include fixed, semi-fixed, and non-fixed elements. Thus, there is a match between the environment, lifestyle, and context. If there is no match in the formation of a space or area, space will lose meaning. A functional road space has a dimensional framework, twodimensional patterns, and also the placement of objects (Trancik, 1986: 70-71).

a. The three-dimensional frame is determined by the edge of space, closure, and the wall-forming space's character. Transparency, opacity, opening, and the surface of the ornament surface impact the space characteristics, such as vertical and horizontal relationships, the relationship between the wall scale road space and the human level, as well as road space floor.

b. Two-dimensional pattern refers to the road space floor's width, both related to the material texture and the composition/polarity of the road.

c. Objects in space, both sculpture, water features, vegetation bringing nuance, and focal points, aims to make space can be remembered by those who are in it. Objects can be used as a point of view and provide space vitality, so object placement can make the impression that the space alive.

Spreiregen in Nugroho (2010: 27) mentions the basic principle of structuring urban elements, one of which is related to the degree of spatial closure. The review function of the degree of space closure is as an analysis technique when road space. The proportion of the degree of closure is assessed based on a comparison of standing people, denoted by the symbol " $D$ " and the height of the building, denoted by the symbol "H".
Table 1. Degree of Space Closure

\begin{tabular}{|l|l|l|}
\hline $\begin{array}{l}\text { Proportio } \\
\mathbf{n}(\mathbf{D} / \mathbf{H}\end{array}$ & Degree of Closure & $\begin{array}{l}\text { Townscape } \\
\text { Influence }\end{array}$ \\
\hline $1: 1\left(45^{\circ}\right)$ & $\begin{array}{l}\text { Full enclosure, space is } \\
\text { very closed if it exceeds } \\
\text { the limit }(\mathrm{D} / \mathrm{H}<1) \\
\text { there will be a pressing } \\
\text { impression }\end{array}$ & $\begin{array}{l}\text { Attention to details of } \\
\text { the entire building }\end{array}$ \\
\hline $1: 2\left(30^{\circ}\right)$ & $\begin{array}{l}\text { Threshold of enclosure, } \\
\text { the lowest limit to form } \\
\text { the impression of a } \\
\text { closed space }\end{array}$ & $\begin{array}{l}\text { Seeing the building } \\
\text { along with overall } \\
\text { detail components }\end{array}$ \\
\hline $1: 3\left(18^{\circ}\right)$ & $\begin{array}{l}\text { Minimum enclosure, } \\
\text { space begins to lose its } \\
\text { closure }\end{array}$ & $\begin{array}{l}\text { See buildings } \\
\text { concerning their } \\
\text { surroundings }\end{array}$ \\
\hline $1: 4\left(14^{\circ}\right)$ & $\begin{array}{l}\text { Loss of enclosure, } \\
\text { space begins to lose its } \\
\text { closure quality }\end{array}$ & $\begin{array}{l}\text { Building as the } \\
\text { foreground in the } \\
\text { overall view }\end{array}$ \\
\hline
\end{tabular}

There are a minimum and maximum limit to the degree of closure. Space of movement, the minimum proportion in creating a degree of closure is $1: 1$, while the maximum proportion is 1: 2.5. In the book titled "An Introduction to Housing Layout" by GLC Study 1978, the space closure can be specified into three sections which are little sense of enclosure, partial enclosure, and strong enclosure.

\section{Research Method}

This study was a descriptive exploratory research, with output in the form of facts as they are. The analysis technique was in the form of superimpose. According to Gulo (2002: 18), explorative descriptive research involves basic questions about 'what' and 'why' to discover a phenomenon by conducting an assessment of the physical speculations. The exploration is to dig up through quantitative or qualitative data.

The output of the analysis were the characteristics of each entrance of the cross passage. Data were collected using direct observation. The number of entrances to the cross passage is determined by the purposive sampling method. Purposive sampling is a technique of taking research objects not based on stratum, random or area, but a particular rule (Arikunto, 2013: 183).

Therefore, the entrance area of cross passage fulfilling the criterion is pointed as a research object. The criterion is "cross passage as the main door to refer to a specific location with sufficient road dimension to be able to be passed through by the movement of people, goods, or vehicles." The scale radius used the physical limit in the form of the nearest cross passage and or a cluster of buildings with a similar pattern. This study found there were 9 cases of the entrance of cross passage used as research objects. The study did not use a sample. However, all cases that meet the criteria will be taken. Table 1 below shows the entrance of the cross passage at the research site (Table 1). 


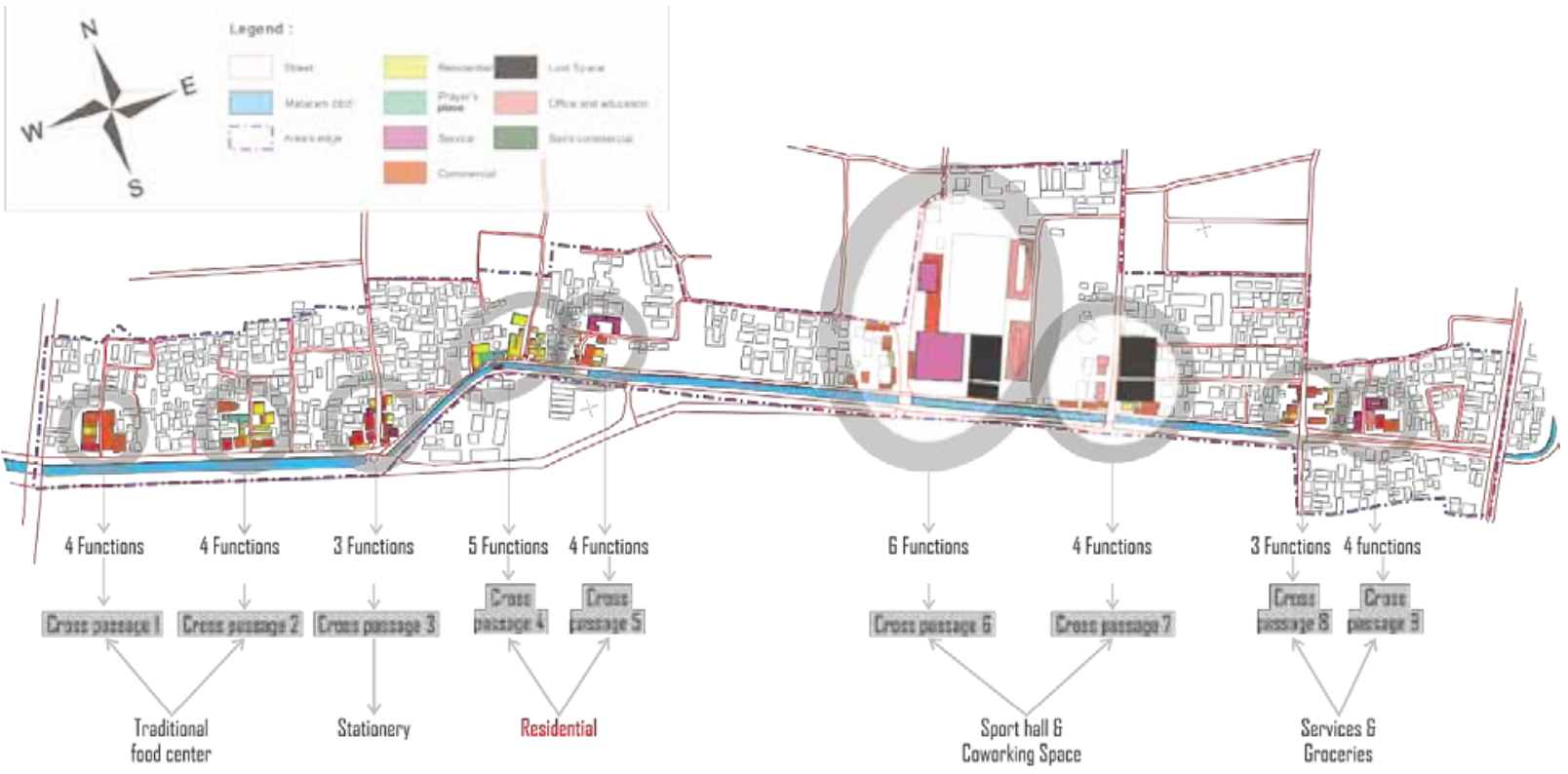

Commercial function in buildings can be categorized based on the cluster of cross passage away area. They are a cluster of cross passage I and 2. cluster of cross passage 3 , cluster of cross passage 6 and 7, and a cluster of cross passage 8 and 9 . Cross passage 3 is categarized as its awn cluster since it has a different selling product. Meanwhile. cross passage 4 and 5 can not be included in a commercial cluster. but still has the same building characteristics. namely residential

Figure 1. Indicates the building function structure

Table 1. Observation Case of Entrance Areas of Cross-Passage

\begin{tabular}{|c|l|l|}
\hline No. & Name of cross passage & Suitability of the criteria \\
\hline 1. & $\begin{array}{l}\text { Jalan Gang Padukuhan } \\
\text { Kocoran, RW 03/ RT 05 }\end{array}$ & $\begin{array}{l}\text { Main entrance to wisma kenzie } \\
\text { and kedai domore. Moreover, it } \\
\text { is also a marker to the area of } \\
\text { Kocoran sub-village }\end{array}$ \\
\hline 2. & $\begin{array}{l}\text { Jalan Gang Cokrowolo, } \\
\text { Kampung Karangasem, } \\
\text { RW 03/ RT 05 }\end{array}$ & $\begin{array}{l}\text { Main access to the center of } \\
\text { Gudeg Yu Djum, region marker } \\
\text { of Karangasem village }\end{array}$ \\
\hline 3. & $\begin{array}{l}\text { Jalan Gang Gayamsari 1, } \\
\text { Padukuhan Karanggayam }\end{array}$ & $\begin{array}{l}\text { Main entrance ot Karanggayam } \\
\text { sub-village. Alternatice access to } \\
\text { north ringroad and Jl. Kaliurang } \\
\text { through Jl. Gg. Megatruh } \\
\text { (Gading mas 1) }\end{array}$ \\
\hline 4. & $\begin{array}{l}\text { Jalan Gang } \\
\text { Jurudemung/Gang } \\
\text { Gayamsari IV, } \\
\text { Lingkungan } \\
\text { Karangbendo }\end{array}$ & $\begin{array}{l}\text { Main entrance to Karangbendo } \\
\text { village. Alternative access to } \\
\text { North Ringroad through Jl. Naga }\end{array}$ \\
\hline 5. & $\begin{array}{l}\text { Jalan Apokat, Gerbang } \\
\text { Kampung Klebengan }\end{array}$ & $\begin{array}{l}\text { Main entrance to Klebengan } \\
\text { village. }\end{array}$ \\
\hline 6. & $\begin{array}{l}\text { Jalan Manggis, GOR } \\
\text { Klebengan }\end{array}$ & $\begin{array}{l}\text { Main entrance to access GOR } \\
\text { Klebengan and Masjid Al Iman. }\end{array}$ \\
\hline 7. & $\begin{array}{l}\text { Jalan Gambir, Kampung } \\
\text { Karangasem baru }\end{array}$ & $\begin{array}{l}\text { Main entrance to access } \\
\text { Kampung Karangasem baru and } \\
\text { Masjid Nurul Asri. }\end{array}$ \\
\hline 8. & $\begin{array}{l}\text { Jalan Flamboyan, } \\
\text { Padukuhan Santren }\end{array}$ & $\begin{array}{l}\text { Entrance to access Santren sub- } \\
\text { village. The intersection area is } \\
\text { the meeting point of opened } \\
\text { Selokan Mataram Canal on the } \\
\text { west and closed canal on the east }\end{array}$ \\
\hline Jalan Gang Dahlia & $\begin{array}{l}\text { Main entrance to access Dahlia } \\
\text { and Oasis hotel. }\end{array}$ \\
\hline
\end{tabular}

\section{Results and Discussions}

\subsection{Building Functions}

Characteristics identification of the building functions to know the surveillance deprivation element.
Table 2. Building function

\begin{tabular}{|c|c|c|c|c|c|c|c|c|c|c|}
\hline \multirow{2}{*}{$\begin{array}{l}\text { Type of } \\
\text { function }\end{array}$} & \multicolumn{9}{|c|}{ Entrance area } & \multirow{2}{*}{$\begin{array}{l}\text { Perce } \\
\text { ntage } \\
\text { (\%) }\end{array}$} \\
\hline & 1 & 2 & 3 & 4 & 5 & 6 & 7 & 8 & 9 & \\
\hline $\begin{array}{l}\text { Commer } \\
\text { cial }\end{array}$ & 2 & 3 & $\begin{array}{l}1 \\
1\end{array}$ & 1 & 1 & 6 & 5 & 8 & 3 & 25.32 \\
\hline $\begin{array}{l}\text { Semi- } \\
\text { commerc } \\
\text { ial }\end{array}$ & $\begin{array}{l}1 \\
0\end{array}$ & 8 & - & - & 3 & 4 & - & 6 & 3 & 21.52 \\
\hline $\begin{array}{l}\text { Residenti } \\
\text { al }\end{array}$ & 2 & 6 & 4 & $\begin{array}{l}1 \\
6 \\
\end{array}$ & 8 & 2 & 2 & - & - & 25.32 \\
\hline Service & 1 & - & 3 & 1 & 3 & 2 & - & 6 & 3 & 12.03 \\
\hline $\begin{array}{l}\text { Education } \\
\text { and office }\end{array}$ & - & 2 & - & - & - & 3 & 3 & - & 2 & 6.33 \\
\hline $\begin{array}{l}\text { Lost } \\
\text { space }\end{array}$ & - & - & - & 1 & - & 2 & 2 & - & - & 3.16 \\
\hline Prayer & - & 3 & - & 7 & - & - & - & - & - & 6.33 \\
\hline
\end{tabular}

The research results were as follows:

a. Buildings with commercial functions formed the entrance area of cross passage. These commercial functions could be categorized based on cross passage clusters. In cross passage 1 and 2, the commercial function was dominant in traditional food stalls. In cross passage 3, it mostly sold stationery. Cross passage 6 and 7 were mostly resided by the sports center and coworking space. In cross passage 8 and 9, commercial functions more on services and groceries. While in cross passages 4 and 5, what seemed dominant was the residential function.

b. Not all building functions located around the cross passage had a direct relationship with universities. Those directly related to universities were cross passages 3,6, and 7. This was based on the type of commercial products targeted to civitas academica. 


\subsection{Height of building}

Building heights at the research site were classified according to the number of floors.

Table 3. The number of floors

\begin{tabular}{|l|l|l|l|l|l|}
\hline \multirow{2}{*}{$\begin{array}{l}\text { Entrance of } \\
\text { cross passage }\end{array}$} & \multicolumn{6}{|c|}{$\begin{array}{c}\mathbf{1} \\
\text { floor }\end{array}$} & $\begin{array}{c}\mathbf{2} \\
\text { floors }\end{array}$ & $\begin{array}{c}\mathbf{3} \\
\text { floors }\end{array}$ & $\begin{array}{c}\mathbf{4} \\
\text { floors }\end{array}$ & $\begin{array}{c}\mathbf{5} \\
\text { floors }\end{array}$ \\
\cline { 2 - 7 } Cross passage 1 & 5 & 8 & 2 & & \\
\hline Cross passage 2 & 9 & 8 & 5 & & \\
\hline Cross passage 3 & 8 & 9 & 1 & & \\
\hline Cross passage 4 & 15 & 4 & 6 & & \\
\hline Cross passage 5 & 13 & 1 & 3 & & \\
\hline Cross passage 6 & 12 & 2 & 3 & & 2 \\
\hline Cross passage 7 & 9 & 1 & 1 & & \\
\hline Cross passage 8 & 15 & & 5 & & \\
\hline Cross passage 9 & 4 & 3 & 3 & 1 & \\
\hline Total & 90 & & 36 & & \\
\hline Percentage (\%) & 56.9 & 22.78 & 18.35 & 0.63 & 1.27 \\
\hline
\end{tabular}

The findings revealed that

a. Almost all the buildings located precisely at the mouth of cross passage did not have the same height (cross passage 1,3,4,6,8 and 9). Therefore, it appeared not proportional or contrasting.

b. The height of the building formed two patterns. First, the building's order was according to the height (dominantly located on the cross passage). Second, the building was clustered with the same height (found in the cross passage). The height of the building showed the static pattern.

c. The contrast patterns of the building height were not just at the mouth of cross passage. However, in some cases, the contrast pattern was found on a linear canal (front) with a building located in a cross passage (behind). A building with a higher part in the back brings the nuance wide for the building next on (cross passage 5,7 , and 9) so that the contrast showed a positive impact.

\subsection{Building setback}

Cluster of setback distance was divided into two: the north side of the canal and on the cross passage. Table 2 indicates the following results

a. Building setback was dominated by a short setback ( 0 to $3.1 \mathrm{~m}$ ). This matter implicated the loss of the yard; some even used the pedestrian path as part of the building.

b. The orientation of the setback determinant influenced a comparison of setback distance variations in the cross-passage entrance and canal. The texture pattern to be formed was curvilinear. Overall, it could be concluded that the setback in the canal linear structure is easier to arrange.

\subsection{Signage}

The identification of signs at the research site had become public (non-commercial) and private (commercial) signs. The commercial sign placement was divided into three: sticking on the building, pedestrian path, and the median of the road. The research results showed that:

a. Sign intensity was directly proportional to the spread of commercial building function and vehicle intensity (cross passage 3,6 , and 8).

b. Signs attached to buildings did not have the same type, location, and size, which tended to show different patterns.

c. On a linear canal road, the sign in the pedestrian acted as additional information in the nearby buildings.

d. Signs positioned on the median, although visible, do not have any significant relationship to the activity in the building or activities around the cross-passage area. Most signs are event-driven.

The following are the types and position of the signs in each cross passage.

Table 4. Setback buildings in linear buildings, canals, and cross passages

\begin{tabular}{|c|c|c|c|c|c|c|c|c|c|c|c|}
\hline \multirow{3}{*}{$\begin{array}{l}\text { Entrance of } \\
\text { cross passage }\end{array}$} & \multicolumn{5}{|c|}{ Buildings on the side of the canal (meters) } & \multicolumn{5}{|c|}{ Buildings on the side of the cross passage (meter) } & \multirow{3}{*}{ Total } \\
\hline & Very short & Short & Average & Very wide & Very wide & Very short & Short & Average & Wide & Very wide & \\
\hline & 0 - 3 & $3.1-6$ & $6.1-9$ & $9.1-12$ & $12.1-15$ & $0-3$ & $3.1-6$ & $6.1-9$ & $9.1-12$ & $12.1-15$ & \\
\hline Cross passage 1 & 1 & 3 & 1 & - & - & 5 & - & - & - & - & 9 \\
\hline Cross passage 2 & - & 3 & - & - & 1 & 5 & - & - & 1 & - & 10 \\
\hline Cross passage 3 & 2 & 3 & - & - & - & 7 & - & - & - & - & 12 \\
\hline Cross passage 4 & 3 & 1 & - & - & - & 2 & - & 2 & - & - & 8 \\
\hline Cross passage 5 & 4 & - & - & - & - & 7 & - & - & 1 & - & 12 \\
\hline Cross passage 6 & 3 & 1 & - & - & 1 & 3 & 2 & - & 1 & - & 11 \\
\hline Cross passage 7 & 4 & - & - & - & - & 2 & 1 & - & - & - & 7 \\
\hline Cross passage 8 & 2 & 1 & - & - & - & 6 & - & 2 & - & - & 11 \\
\hline Cross passage 9 & 2 & 1 & 1 & - & - & 3 & 1 & 1 & - & - & 9 \\
\hline Total & 20 & 13 & 2 & 0 & 2 & 40 & 4 & 5 & 3 & 0 & 89 \\
\hline Percentage (\%) & 22.47 & 14.61 & 2.25 & & 2.25 & 44.94 & 4.49 & 5.62 & 3.37 & & \\
\hline
\end{tabular}


Table 5. Type of position of sign in each area of cross passage

\begin{tabular}{|c|c|c|c|c|c|c|c|c|c|}
\hline \multirow{3}{*}{$\begin{array}{l}\text { Cros } \\
\text { s } \\
\text { pass } \\
\text { age }\end{array}$} & \multicolumn{4}{|c|}{ Canal linear road } & \multicolumn{3}{|c|}{$\begin{array}{c}\text { Cross passage } \\
\text { road }\end{array}$} & \multirow{3}{*}{$\begin{array}{l}\text { To } \\
\text { tal }\end{array}$} & \multirow{3}{*}{$\%$} \\
\hline & \multicolumn{3}{|c|}{$\begin{array}{l}\text { Commercial } \\
\text { signboard }\end{array}$} & \multirow{2}{*}{$\begin{array}{l}\begin{array}{l}\text { Non- } \\
\text { comme } \\
\text { rcial } \\
\text { sign }\end{array} \\
\text { RnK }\end{array}$} & $\begin{array}{l}\text { Comn } \\
\text { al } \\
\text { signb }\end{array}$ & & $\begin{array}{l}\text { Non- } \\
\text { comme } \\
\text { rcial } \\
\text { sign } \\
\end{array}$ & & \\
\hline & $\begin{array}{c}\mathbf{R k} \\
\mathbf{B} \\
\end{array}$ & $\begin{array}{c}\mathbf{R} \\
\mathbf{k P}\end{array}$ & $\begin{array}{l}\mathbf{R k} \\
\mathbf{M}\end{array}$ & & $\begin{array}{c}\mathbf{R k} \\
\mathbf{B}\end{array}$ & $\begin{array}{r}\mathbf{R} \\
\mathbf{k P}\end{array}$ & RnK & & \\
\hline Сp 1 & 3 & 3 & & 1 & & & & 7 & $\begin{array}{r}2.5 \\
9\end{array}$ \\
\hline Cp 2 & 11 & 10 & 2 & 3 & 6 & & 2 & 34 & $\begin{array}{r}12 . \\
59\end{array}$ \\
\hline Cp 3 & 12 & 4 & 6 & 7 & 18 & 4 & & 51 & $\begin{array}{r}18 . \\
89\end{array}$ \\
\hline Cp 4 & 1 & 2 & 1 & 5 & & & & 8 & $\begin{array}{r}2.9 \\
6\end{array}$ \\
\hline Cp 5 & 2 & & & 2 & 9 & & 4 & 17 & $\begin{array}{r}6.3 \\
0\end{array}$ \\
\hline Cp 6 & 17 & 11 & 4 & 2 & 16 & 4 & 1 & 55 & $\begin{array}{l}20 . \\
37\end{array}$ \\
\hline Cp 7 & 17 & 2 & 9 & 2 & 1 & 6 & 2 & 39 & $\begin{array}{r}14 . \\
44\end{array}$ \\
\hline Cp 8 & 12 & 8 & 6 & 5 & 6 & 4 & & 41 & $\begin{array}{l}15 . \\
19\end{array}$ \\
\hline Cp 9 & 8 & 4 & 2 & 1 & 3 & & & 18 & $\begin{array}{r}6.6 \\
7\end{array}$ \\
\hline Total & 83 & 44 & 29 & 28 & 59 & 18 & 9 & $\begin{array}{r}27 \\
0\end{array}$ & $\begin{array}{r}10 \\
0\end{array}$ \\
\hline$\%$ & $\begin{array}{l}30 . \\
74\end{array}$ & $\begin{array}{r}16 . \\
3\end{array}$ & $\begin{array}{l}10 . \\
74\end{array}$ & 10.37 & $\begin{array}{r}21 . \\
85\end{array}$ & $\begin{array}{r}6.6 \\
7\end{array}$ & 3.33 & 100 & \\
\hline
\end{tabular}

Source: the 2019 source of survey

$$
\begin{aligned}
& \text { Description } \\
& \text { 1. Percentage } 0-10 \% \text { Low intensity } \\
& \text { 2. Percentage } 10.1 \%-15 \% \text { : medium intensity } \\
& \text { 3. Percentage } \geq 15,1 \% \text { : High intensity }
\end{aligned}
$$

\section{Notation description}

RkB : Commercial signboard stuck on the building

RkP : Commercial signboard stuck on pedestrian/road

RkM : Commercial signboard stuck on road median

\subsection{Floor of the road space}

Road space floor would identify road space dimensions, road space pattern, and the pavement in each cross passage. The findings showed that the floor is constructed with sufficient hardening conditions. The road space in each cross passage had different dimensions, numbers, and heights. For example, in cross passage 8 , if the linear driver followed a curve, the cross passage, alley, and canal would act as the median of the road. However, after passing through intersection, the road median was concrete. Selokan Mataram Canal gets under the road. Another thing with cross passage 6 was the height of the road and the curved road body, which indicated narrowness. Therefore, cross passage 6,7 , and 8 always be a traffic jam. Meanwhile, pedestrian path conditions on the linear canal road were good but less effective since some were used for parking and street vendors. There was no pedestrian route yet on the cross passage. The following is the dominant pattern of road space floor in each cross passage.

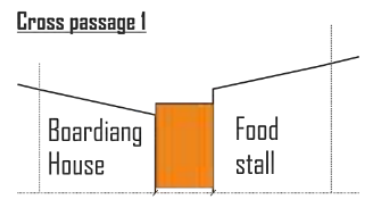

Paving black 5 meters road space

\section{Cross passage 2}

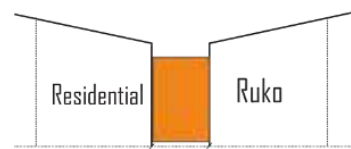

Paving black 5 meters road space

Cross passage 3

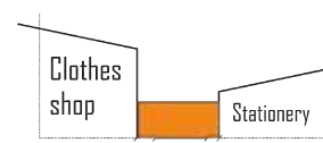

Asphalt $\quad 8.4$ meters road space

Cross passage 4

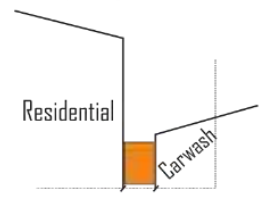

Concrete rebate

3,3 meters road space

\section{Cross passage 5}
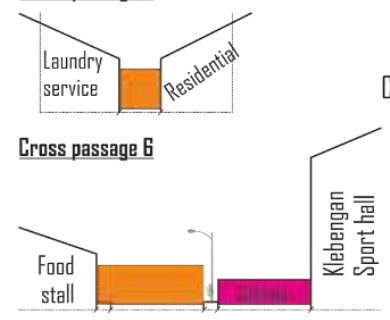

Concrete rebate $\quad 3,5$ meters road space

Cross passage 7
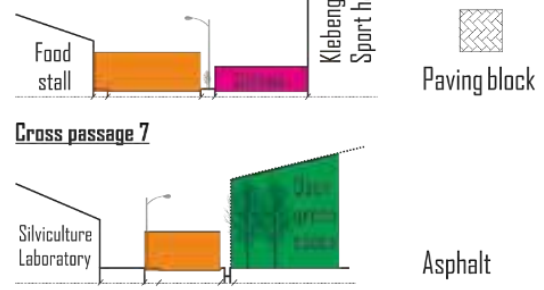

9 meters road space 88 meter setback, 1,5 Paving black meters pedestrian

6.5 meters road space, I meter pedestrian

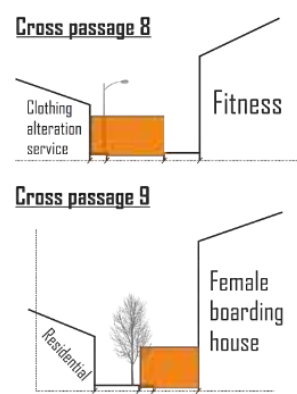

Asphalt

Asphalt $\quad 6.5$ meters road space

Asphalt 5 meters road space

Figure 2. Road space floor pattern

\subsection{Vegetation}

Vegetation classification is based on vegetation located on linear canal or cross passage. The trends in vegetation are as follows.

1. Dominant vegetation lied at the edge of the canal with a shade function. Meanwhile, on the cross passage, vegetation was predominant for ornamental functions.

2. Vegetation located on private land (yard) was dominated by vegetation with a short height and broad canopy.

3. Vegetation on road space was dominated by medium to high vegetation (an average of $3 \mathrm{~m}$ ), with a short to broad canopy (an average of $4 \mathrm{~m}$ ). 


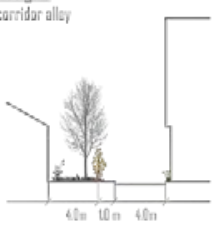

Cross passage 2

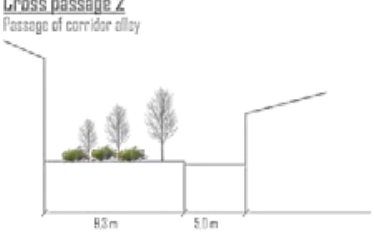

Cross passage 3

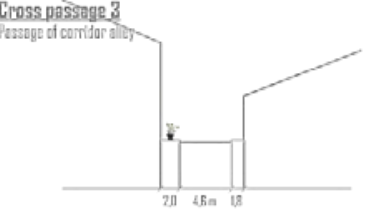

Crass passage 4

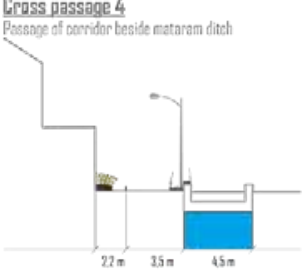

Cross passage 5

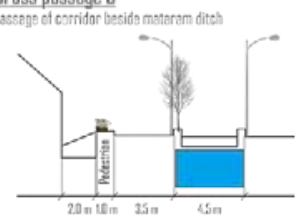

Figure 3. Vegetation pattern

Meanwhile, the findings of the analysis showed the vegetation trend located at the edge of Selokan Mataram Canal, so the canal contributes to the green forest and surrounding entrance area of the cross passage. The canopy predominance with a width of more than $3 \mathrm{~m}$ is located at the edge of Selokan Mataram Canal; therefore, the edge of the canal had more shade nuance than the mouth of cross passage. The entire vegetation is dominated by ornamental plants. Vegetation, which is an ornamental plant, is on private land, and at the same time, is a pseudo boundary of ownership. The vines on the walls and fence become the identity of the surveillance.

\subsection{Street furniture}

Street furniture elements were classified based on spot and network categories. Street furniture categorized in the network were the street lamp, electric pole, and fiber optic pole. Meanwhile, the elements of street furniture included in the spot category were transportation, trash, flagpole, sculpture, gate, and bollard. The following was the street furniture elements in each cross passage and the location of the placement.

Table 6. Type and location of street furniture

\begin{tabular}{|c|c|c|c|c|c|c|c|c|c|}
\hline \multirow{2}{*}{$\begin{array}{l}\text { Type of } \\
\text { street } \\
\text { furniture }\end{array}$} & \multicolumn{9}{|c|}{ Type of Cross-passage (cp) } \\
\hline & $\begin{array}{c}\text { Cp. } \\
1\end{array}$ & $\begin{array}{c}C \mathrm{Cp} \\
2\end{array}$ & $\begin{array}{c}\text { Cp. } \\
3\end{array}$ & $\begin{array}{c}\text { Cp. } \\
4\end{array}$ & $\begin{array}{c}\text { Cp. } \\
5\end{array}$ & $\begin{array}{c}\text { Cp. } \\
6\end{array}$ & Cp. & $\begin{array}{c}\text { Cp. } \\
8\end{array}$ & $\begin{array}{c}\text { Cp. } \\
9\end{array}$ \\
\hline $\begin{array}{l}\text { Desk or } \\
\text { Train }\end{array}$ & & & & & & & $\sqrt{ }$ & $\sqrt{ }$ & \\
\hline
\end{tabular}

\begin{tabular}{|c|c|c|c|c|c|c|c|c|c|}
\hline Trash can & & $\sqrt{ }$ & & & & & $\sqrt{ }$ & & \\
\hline $\begin{array}{l}\text { Street } \\
\text { lights }\end{array}$ & $\sqrt{ }$ & $\sqrt{ }$ & $\checkmark$ & $\sqrt{ }$ & $\checkmark$ & $\sqrt{ }$ & $\sqrt{ }$ & $\sqrt{ }$ & $\sqrt{ }$ \\
\hline power pole & $\sqrt{ }$ & $\sqrt{ }$ & $V$ & $\sqrt{ }$ & $V$ & $\sqrt{ }$ & $\sqrt{ }$ & $\checkmark$ & $\sqrt{ }$ \\
\hline $\begin{array}{l}\text { Fiber optic } \\
\text { pole }\end{array}$ & $\sqrt{ }$ & $\sqrt{ }$ & $\checkmark$ & $\checkmark$ & $\checkmark$ & $\sqrt{ }$ & $\sqrt{ }$ & $\checkmark$ & $\sqrt{ }$ \\
\hline Bollard & $\sqrt{ }$ & & & & & & $\sqrt{ }$ & & \\
\hline $\begin{array}{l}\text { Flagpole } \\
\text { hold }\end{array}$ & & $\sqrt{ }$ & $\sqrt{ }$ & $\sqrt{ }$ & $\sqrt{ }$ & & & & \\
\hline Gate & $\sqrt{ }$ & $\sqrt{ }$ & & $\sqrt{ }$ & $\sqrt{ }$ & $\sqrt{ }$ & $\sqrt{ }$ & $\sqrt{ }$ & $\sqrt{ }$ \\
\hline Sculpture & & & & & $\checkmark$ & & $\sqrt{ }$ & $\checkmark$ & \\
\hline \multicolumn{10}{|l|}{ Position } \\
\hline $\begin{array}{l}\text { Near side } \\
\text { of the road }\end{array}$ & $\sqrt{ }$ & $\sqrt{ }$ & $\sqrt{ }$ & $\sqrt{ }$ & $\sqrt{ }$ & $\sqrt{ }$ & $\sqrt{ }$ & $\sqrt{ }$ & $\sqrt{ }$ \\
\hline On setback & & & $\sqrt{ }$ & & $\sqrt{ }$ & & & & \\
\hline $\begin{array}{l}\text { Near } \\
\text { buildings }\end{array}$ & & & & $\sqrt{ }$ & & & & & \\
\hline
\end{tabular}

Street furniture that was always there in each crosspassage area was only a part of the primary needs of activities in the building. Meanwhile, spot street furniture, such as the park, bollards, flags, and places of waste, were not evenly distributed. Whereas, street furniture, which was spot in nature, had more aesthetic elements and more useful for outdoor activities, and could show deviant characteristics. The existence of the gate and sculpture were as an observation area, but because they were placed right at the mouth of cross passage, it just narrows down the geometric path.

\subsection{Road space scale}

The road space scale was an analysis to see the quality of external space in horizontal and vertical fields. Input data in the room-scale were the data setback, the dimension of the road space, and the height of the building. The scale of the space could be passed through townscape analysis, where it was valued based on the comparison of standing people (D) and the building height $(H)$. The output from the road space scale was the level of space closure. Here are the results of the road scales on each entrance area of cross passage.

Table 7. The degree of space enclosure

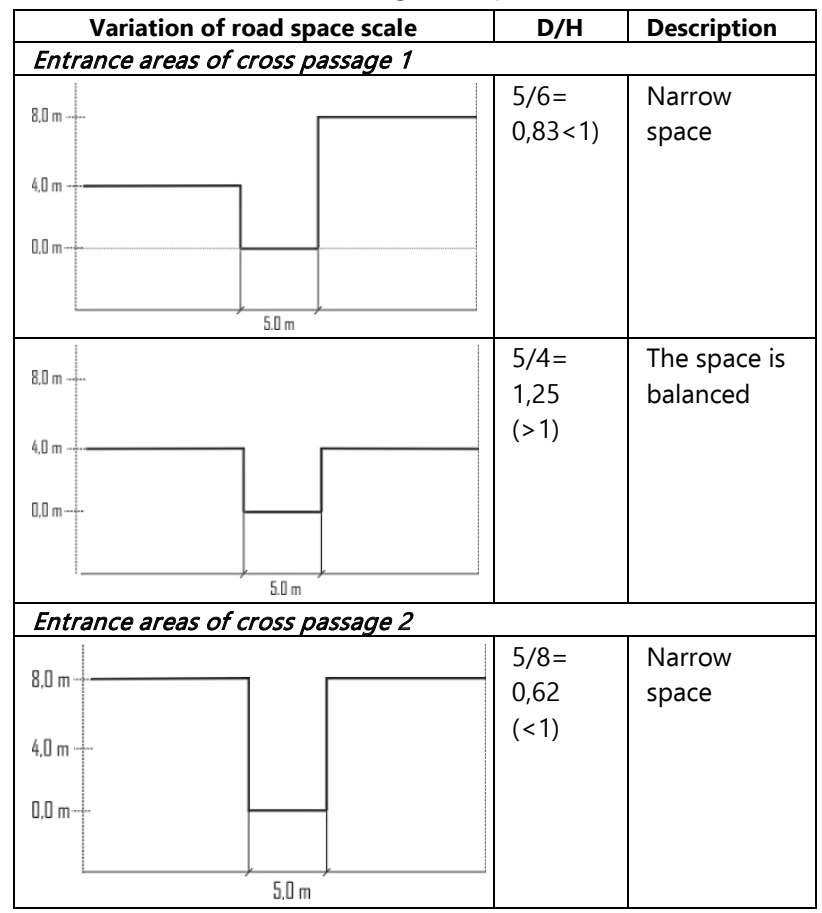




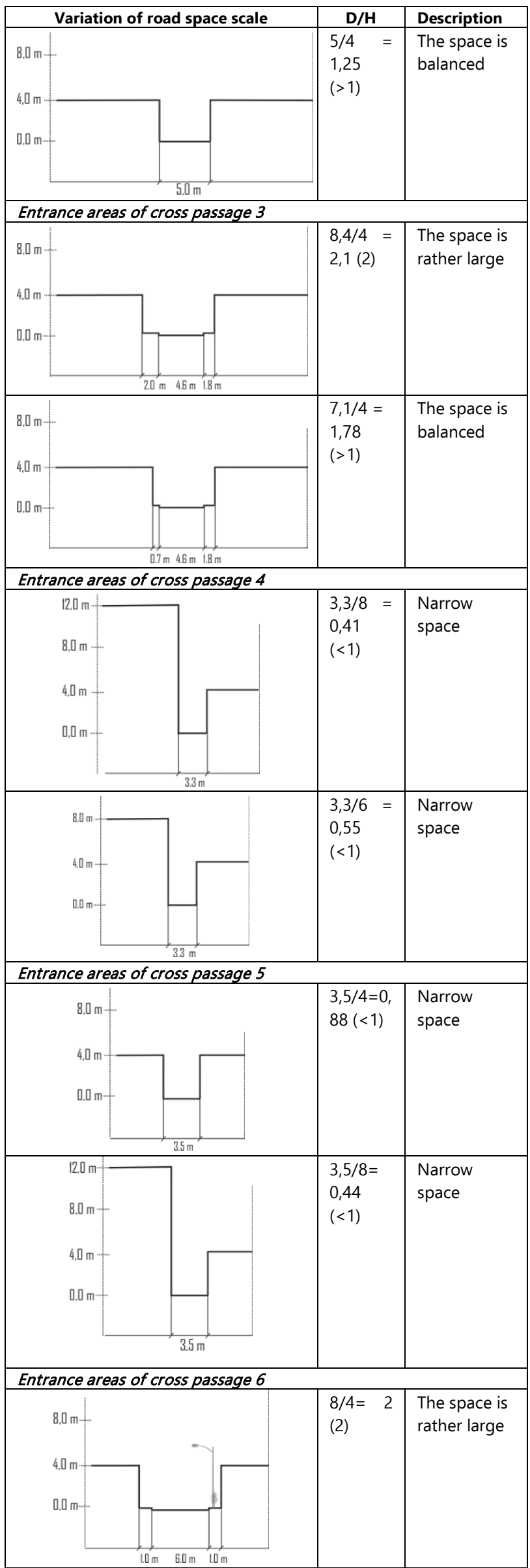

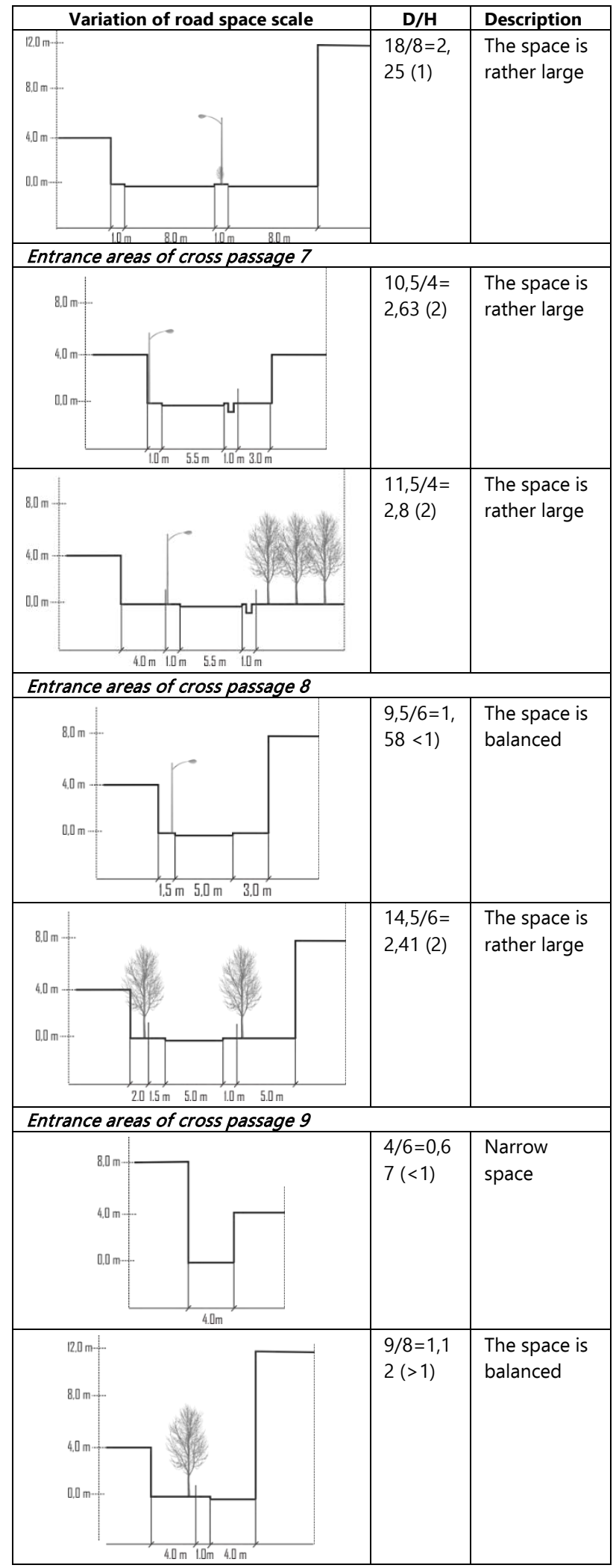

A. Trends

1. The scale of the road space on the cross passage was dominated by narrow and balanced space. For the linear canal roads, the dominant drainage scale is balanced and rather large

2. A small road scale cut was located at the mouth of cross passage.

3. Commercial buildings form the dominant wall space

4. Setback distance, which seemed to be the same, did affect the scale of the space. 


\section{B. Findings}

There were two dominance road formed: narrow and space balanced. The spatial scale of canal linear path was broad, the balanced scales of the space were only in the northern sideways space of the canal where the vegetation intensity at the edge of the canal was broad, having a double median, and the walls of the path formed by the buildings in the floor (cross passage 6,7 and 8). The road space scale of the cross-passage mouth was narrow. Setback had no signification influence on the road scale.

\subsection{Superimpose}

A superimposed map is useful for knowing the characters in each area around the cross-passage entrance. All physical elements will be extensively studied for its relevance to the superimposed map. The superimposed map will focus on the three-dimensional framework, since it becomes the output of objects in space and the twodimensional framework. The following is the superimposed map on each area of cross passage entrance.

Table 8. Three-dimensional Frame

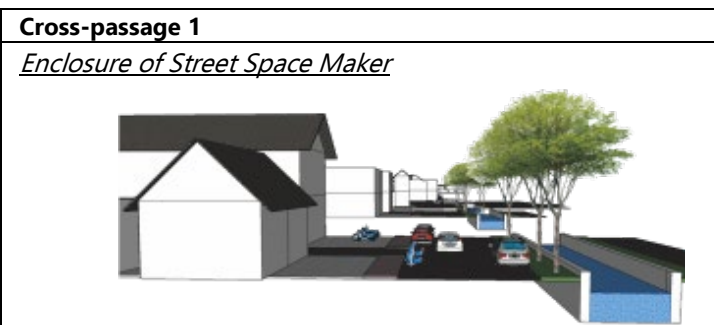

The north side is formed by the walls of 'gudeg' stalls and bookstores. The average setback is 3.1 to $6 \mathrm{~m}$. While on the south side, the walls are formed by soft enclosures in the form of vegetation. The average height is $4 \mathrm{~m}$, and the canopy width is 3 to $5 \mathrm{~m}$.

\section{Street Space Scale}

The space scale on the cross passage is narrow and balanced/harmonious. Meanwhile, on the linear street, the canal has a wide scale space.

\section{The linkage between vertical and horizontal}

Space is created by different road space. On the cross passage, the hard enclosure is formed by commercial buildings. The height of the building has a significant effect on the formation of the street space scale. Meanwhile, the side of the linear canal street is formed by commercial buildings and vegetation.

\section{Cross-passage 2}

\section{Enclosure of Street Space Maker}

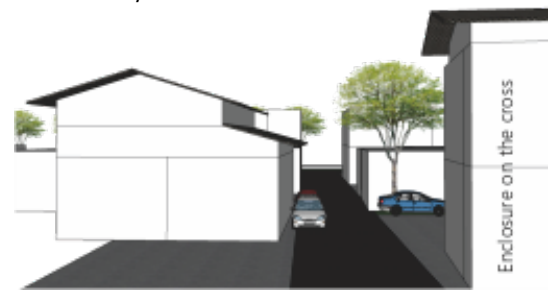

On the linear canal street, the north side is formed by the walls of the commercial buildings, such as post office and musical instrument shops. Meanwhile, the south side is formed by tree and bushes. Also, the hard enclosure is formed by a combination of residential, sub-village offices, place of worship, and semicommercial building (gudeg stalls). The height and width of the canopy are sufficient for shade functions. Overall setback average is 0 to $3 \mathrm{~m}$. The mouth of the cross passage seems narrow, but will be wider after walking more ahead. It is influenced by building setback, which is narrow at the entrance but broad at the end.

\section{Street Space Scale}

On the cross passage, the street scale is a combination of the narrow and harmonious spaces. Meanwhile, on the linear street, the canal has a wide-scale space.

\section{The linkage between vertical and horizontal}

Street spaces are formed with different scales. On the linear street, canal has a rather ample road space. Meanwhile, at the entrance of the cross passage, it seems narrow, but after walking more ahead, the street seems balanced. Therefore, the space on the cross passage is a combination of narrow to balanced space scale.

\section{Cross-passage 3}

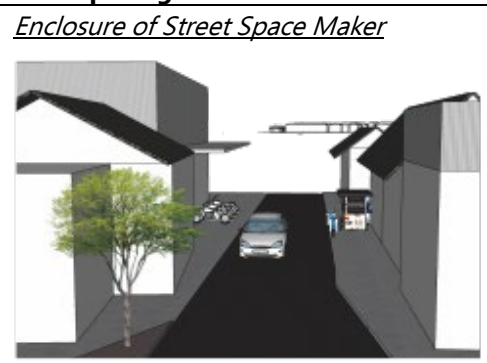

Enclosure on the cross passage

\section{Hard enclosure are} formed by the walls of commercial buildings and vegetation along the canal. On the cross passage, the wall is formed by commercial buildings, such as shops and food stalls

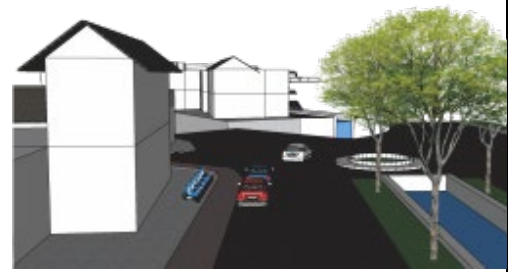

Enclosure on the linear road

\section{Street Space Scale}

The space scale of the cross passage is harmonious. On the linear street, the canal has a broad street scale.

\section{The linkage between vertical and horizontal}

The linear side of the canal has a rather ample road space at the entrance. At the entrance of the cross passage, space is actually not too narrow, but because of on-street parking space, it seems narrow. The entrance area of this cross passage is a 6-junction road, with 2 alternating sections and 4 unidirectional sections. The lack of wayfinding on location causes road users to often miss orientation in taking the lane.

\section{Cross-passage 4}

Enclosure of Floor Space Maker

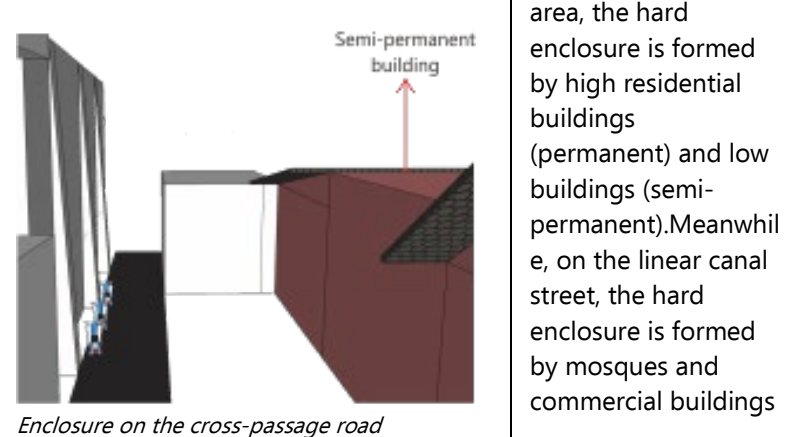

\section{Street Space Scale}

Overall, it has a narrow scale of space

\section{The linkage between vertical and horizontal}

On the cross passage, the road space scale is narrow.

Motorcyclists must take turns when passing through. It is also cannot be passed by cars. Factors affecting the scale of street space are the dimensions and the steep elevation of the street. Meanwhile, on the linear canal street, the street space scale is harmonious. However, the obstacles are the parking spaces, impressing narrow road space.

\section{Cross-passage 5}

Enclosure of Street Space Maker 


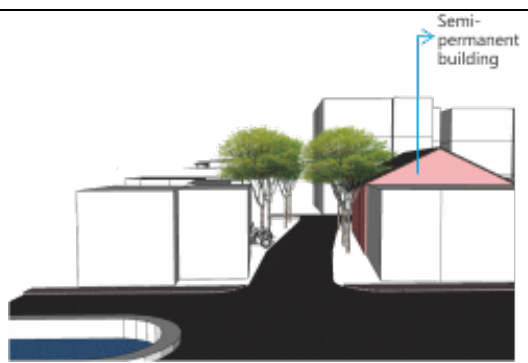

The hard enclosure of the cross passage is formed by semipermanent housing and vegetation. Meanwhile, on the linear canal street, the hard enclosure is formed by commercial buildings on the north side and the UGM Campus fence on the south.

\section{Street Space Scale}

On the cross passage, the space scale is very narrow. On the linear street, the canal has a rather large scale of space.

\section{The linkage between vertical and horizontal}

Space is formed with different scales. The space on the cross passage is formed by: 1) semi-permanent residential walls and vegetation; 2) short setback; 3) narrow space scale; 4 ) on-street parking space. The existing vegetation reduces the dimensions of the road. Meanwhile, on the linear canal street, the space is formed by semi-commercial buildings and campus fences, with large-scale spaces. There is a difference in the elevation of the building floor and the street floor. Existing buildings tend not to have a setback. Existing pedestrians are blocked by vegetation, which interferes with pedestrian circulation. Overall street circulation is not hampered, the existing street capacity is still sufficient to accommodate street users

\section{Cross-passage 6}

\section{Enclosure of Space Street Maker}

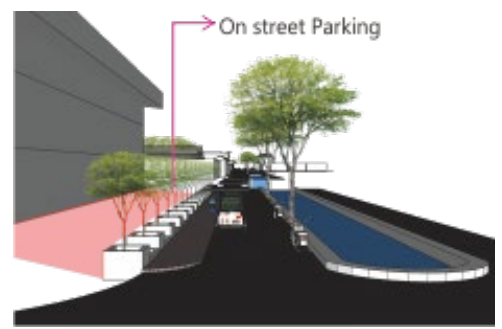

The hard enclosure is formed by commercial buildings on the west and GOR on the east. On the linear canal street, the hard enclosure is formed by the GOR building on the north and vegetation as well as UGM campus on the south.

\section{Street Space Scale}

Cross passage has a broad scale of space. On the linear road, the canal has broad and harmonious space scales

\section{The linkage between vertical and horizontal}

There is no significant difference in the space scale of each street section. The parking location reduces the dimensions of the street but does not interfere with street circulation.

The setback has no significant effect on the scale of street space. On the linear canal street, the enclosure was formed by the GOR and UGM campus fence. The function of the pedestrian path is lack optimal. On the cross passage, the enclosure is formed by a wall dominated by trees with a small canopy.

\section{Cross-passage 7}

\section{Enclosure of Street Space Maker}

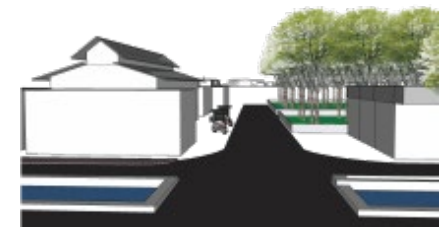

The hard enclosure on the linear canal street is formed by commercial buildings on the left and vegetation on the edge of the canal. On the cross passage, the wall space is formed by the silviculture laboratory and arboretum.

\section{Street Space Scale}

The cross passage has a broad scale of space. On the linear canal street, the space scale is harmonious

\section{The linkage between vertical and horizontal}

Space is formed with different scales. The setback is almost the same in one region. Road dimensions at the mouth of the cross passage are narrow, thus inhibiting circulation. On the linear canal street, the enclosure is formed by commercial buildings and vegetation. On the cross passage, the enclosure is formed by the Silviculture laboratory and vegetation. Vegetation on the cross passage is quite massive, but the lighting (street furniture) is lacking at night.

\section{Cross-passage 8}

Enclosure of Street Space Maker

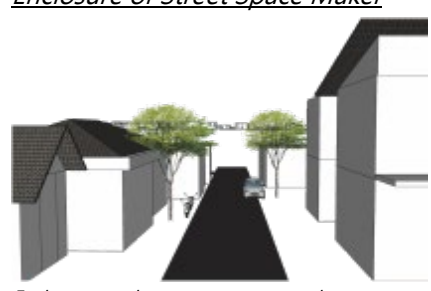

Enclosure on the cross-passage road

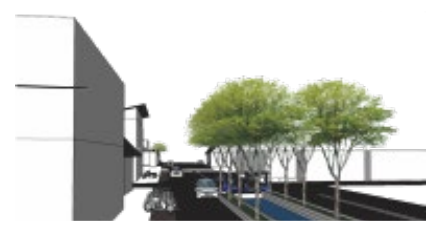

Enclosure on the linear road

\section{Street Space Scale}

On the linear road, the canal has a wide scale space. The cross passage has a harmonious space scale.

\section{The linkage between vertical and horizontal}

Space is formed with almost the same scale of space. On the linear canal space, the enclosure is formed by commercial buildings and vegetation. Then, at the intersection, it becomes an opened and closed meeting point of the canal. As a result, street space is formed by different dimensions and flow patterns. This affects the placement of signage, street furniture, and street space floor patterns. On the cross passage, enclosures are formed by shelter and vegetation. Building's setback in the middle of the cross passage is quite wide, around 6.1 to $9 \mathrm{~m}$.

\section{Cross-passage $\mathbf{9}$}

Enclosure of Street Space Maker

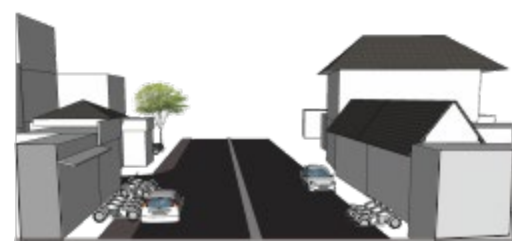

The hard enclosure on the north is formed by commercial buildings and the south is formed by residential buildings. On the cross-passage street, the hard enclosure is formed by vegetation and service buildings. The height of the building contrasts between the building in front and back. The tall building in front looks like a mirror for the one-store building in front of it. The contrast side actually increases the visual quality of the area.

\section{Street Space Scale}

The linear canal street has a wide space scale, while the crosspassage street has a narrow space scale.

\section{The linkage between vertical and horizontal}

The hard enclosure is formed by different spatial scales. Overall: 1) the height of the building between the front and back of the cross passage is contrast; 2 ) the vegetation is only a little; 3 ) There is an integrated sign in the street median; 4) the setback is short. On the linear canal street, a commercial wall is formed on the north sand residential on the south side. On the cross passage, the hard enclosure is formed by residential and service buildings. 


\section{Conclusion}

The physical characteristics of the entrance areas of cross passage along Jl. Agro, Yogyakarta have their own uniqueness. Of the 9 (nine) regions, they can be summarized into five zones: a) Cross passage 1 of Kocoran sub-village and cross passage 2 of Karangasem sub-village as traditional food centers; b) cross passage 3 of Karanggayam sub-village as a stationery store; c) cross passage 4 of Gayamsari village and cross passage 5 of Klebengan village as a squatter area; d) cross passage 6 (GOR Klebengan), and cross passage 7 (Karangasem baru); and cross passage 3 ) is the area of the sports center, arboretum, and coworking spaces as the area of campus' outdoor activities; and e) cross passage (Padukuan Santren) and cross passage 9 (Dahlia cross passage) as service centers. The control characteristics of each zone are as follows.

a. Zone 1 (Cross passage 1 and 2)

Wall space is formed by commercial buildings, with the main products of exceptional traditional food. Short setback ( 3.1 to $6 \mathrm{~m}$ ) in a linear canal and very short buildings ( 0 to $3 \mathrm{~m}$ ) are built on the cross passage. Low signage intensity; the on-road signage space is the additional information for nearby commercial activities. The road space floor on the cross passage uses a paving block pavement, with a dimension of $5 \mathrm{~m}$ and a 'road-body building' pattern. Vegetation on private land turns to be an ornamental plant with aesthetic function. The scale of the road space on the cross passage is a combination of narrow and balanced spaces. The character of zone 1 is partial enclosure.

b. Zone 2 (Cross passage 3)

Wall space is formed by commercial buildings with the main products of stationery. The height of the linear array of buildings depends on the number of floors. Commercial sign on the building dominantly closes the facade. There is almost no vegetation on the cross passage. The existing road segments cause miss orientation for the rider because there are six arm segments connected by one intersection. The scale of the space is a combination of balanced and rather large spaces. The character of zone 2 is little of sense enclosure.

c. Zone 3 (Cross passage 4 and 5)

The building walls are formed by permanent and semi-permanent housing. Street space floor pattern is building-road-building. Pavement on the cross passage of concrete rebate with a road dimension of 3.3 to $3.5 \mathrm{~m}$. Residential is formed organically, with a group and massive patterns. Road to the residence, steep and narrow road elevation, cannot be passed by cars. There is almost no commercial sign. Vegetation is dominated by ornamental plants, with as an aesthetic plant, limiting ownership, remaining space fillers, and more showing the same characteristics in one environment. The character of zone 3 is strong enclosure. d. Zone 4 (Cross passage 6 and 7)

Wall space is formed by commercial buildings and vegetation. The building is composed of a sports center, student dormitory, and a silviculture laboratory (campus' extra space). Having 2 road medians, canal and concrete. Both intersections become the epicenter of congestion. Placement, type, and size of the sign is quite orderly. The existing road media becomes a special location to sign the event. Vegetation is spread evenly. With a mixture of planting patterns, both flowers, shrubs, and grass are planted in the same spot. Street furniture is quite complete, but the lighting in the cross passage is lacking. The character of zone 4 is little of sense enclosure.

e. Zone 5 (Cross passage 8 and 9)

Road space walls are formed by vegetation and semicommercial buildings, with service products. The road space floor on the cross passage is formed with asphalt pavement and the dimensions of 4 to $5 \mathrm{~m}$. Having a double road median with a different pattern. First, canal and concrete canal es. Second, the concrete with the canal is underneath. This happens because, in this zone, there is a change in the canal channel from what was previously open (surface) to closed (subsurface). The setback is very short ( 0 to 3 $\mathrm{m}$ ) at the cross-passage's mouth, but in the middle of the cross passage, the setback is average (6.1 to $9 \mathrm{~m}$ ). This affects the scale of road space. The location of the vegetation with the height and width of the crown is on the cross passage. Vines on the walls and fences give an aesthetic impression. The road space scale on the cross passage is a combination of narrow, balanced, and rather wide spaces. The character of zone 5 is partial enclosure.

\section{References}

Arikunto, S. (2013). Prosedur Penelitian Suatu Pendekatan Praktik. Jakarta: Rineka Cipta.

Gulo, W. (2002). Metodologi Penelitian. Jakarta: PT. Gramedia Widiasarana Indonesia.

GLC Study. (1978). An Introduction to Housing Layout. London: Greater London Council.

Lynch, Kevin. (1960). The Image of The City. Massachusetts Institute of Technology Cambridge, Massachusetts, and London, England.

Nugroho, Agung. (2009). Kampung Kota sebagai Sebuah Titik Tolak dalam Membentuk Urbanitas dan Ruang Kota Berkelanjutan. Jurnal Rekayasa Vol. 13, Desember 2009.

Pangarsa, G. (2010). Ruang Arsitektur di Arsitektur Nusantara: Rong dan Bukan-Rong. Jurnal. Malang: Universitas Brawijaya.

Setiawan, H. (2008). Arsitektur, Lingkungan dan Perilaku. Yogyakarta: Gadjah Mada University Press.

Trancik, Roger. (1986). Finding Lost Space. New York: Van Nostrand Reainhold Company.

Wismarani, Yustina Banon. (2017). Kondisi Livabilitas Koridor Jalan: Studi Kasus: Jalan Selokan Mataram Canal Pada Penggal Jalan Affandi Sampai Seturan Raya, Yogyakarta. Jurnal Arsitektur Komposisi. Volume 11 Nomor 5. 